\title{
INTERACTIVE TECHNOLOGIES OF TRAINING TEACHERS FOR ORGANIZING LEISURE ACTIVITY
}

\section{Oksana Nozdrova}

Candidate of Pedagogical Sciences, Senior Lecturer at the Department of Pedagogy, South Ukrainian National Pedagogical University named after K. D. Ushynsky, Ukraine e-mail: katenozdrova654@gmail.com, orcid.org/0000-0003-2988-7912

\section{Iryna Bartienieva}

Candidate of Pedagogical Sciences, Senior Lecturer at the Department of Pedagogy, South Ukrainian National Pedagogical University named after K. D. Ushynsky, Ukraine e-mail: irina021271@ukr.net, orcid.org/0000-0003-3420-2965

\section{Andrzej Kryński}

Professor, Ph.D., Polonia University in Czestochowa, Interdisciplinary Faculty, Poland e-mail: a.krynski@ap.edu.pl,orcid.org/0000-0001-9635-023X

\section{Summary}

Features of preparation of future teachers for carrying out of interactive training technologies in the course of the organization of leisure activity in the conditions of rest in summer camps are examined. It is noted that various forms of leisure activities in the summer camp can support the emotional health of children, overcome their own shortcomings, form the will and character.

Advice and methods for conducting the case method are given: selection of material (material should be selected in such a way as to reflect the problems that participants may face in real life); the availability of alternatives (the situation around which the discussion takes place should have been sufficiently diverse and have several solutions).

The advantages of the case method are described: realism (the use of this method significantly complemented the theoretical aspects of the problem); pressure reduction (case method gave a unique opportunity to study complex or emotionally significant issues in a safe training atmosphere, not in real life, with real threats and risks in case of making the wrong decision); active interaction (communicative nature of the method provided an opportunity to provide a quick but very important assessment of the issues under discussion and the proposed solution).

It is proved that interactive pedagogical technology in the process of organizing leisure activities of a person (as a set of a series of consecutive actions aimed at achieving a result) was based on the principles of voluntariness, positivity, responsibility, partnership.

Keywords: interactive training technology, case method, leisure activities for children, summer camp, future teachers.

\section{DOI: https://doi.org/10.23856/4611}

\section{Introduction}

In the conditions of pedagogical innovations changes in activity of professional educational institutions acquire special value. This implies a reorientation of forms and methods of organizing the educational process, which would correspond to the peculiarities of the current socio-cultural situation and the tasks of updating the system of vocational education. 
From these positions, the application of innovative modeling in the training of future professionals is important for the formation and development of professional competence of professionals.

\section{Presentation of the main research material}

Modern practice of pedagogical activity involves the use of various forms technological in their content and process. They attract more and more attention of both theorists and practitioners (I. Bekh, A. Kapska, V. Kravets, V. Sidorov, S. Kharchenko), as they provide an opportunity to constantly update knowledge and skills in accordance with the requirements of the time. Therefore, the main issue facing pedagogical practices now is the acquisition of skills and abilities of personal self-development, increasing the level of professional competence, which is largely solved by introducing interactive technologies, organizing the transfer of socially significant information, finding answers to questions: "how to teach, how to create the necessary conditions" (Bachkov, 2000: 198).

This is the application of interactive learning with deep social content. The peculiarity of interactive learning is that the learning process is carried out under the condition of constant, active interaction of all its members. This is the use of business, role-playing games, discussions, conferences. Their goal is to change and improve the behavior patterns of participants in the learning process.

Analyzing their own reactions and the partner's reactions, the participant changes his model of behavior and consciously adopts it, which allows us to consider interactive methods not only as a learning, but also education process (Velichko, Karpievich, 2001:100).

Definition of previously unsolved parts of the overall problem. In the study, we reveal the features of training future teachers to conduct interactive technologies during the organization of children's leisure activities in the conditions of recreation in summer camps. The special value of meaningful and interestingly organized summer leisure is that it can help to realize all the best that is potentially inherent in the child. Various forms of leisure activities help to maintain emotional health, overcome personal shortcomings, form will and character.

The problem of summer leisure was studied by V. Bochelyuk, V. Pimenov, who considered the structure, functions and principles of leisure activity; E. Aknaev, M. Bushanets, T. Melnychuk singled out the organization of work in the field of leisure in their works.

The purpose of the study is to reveal the features of training future teachers to conduct interactive training technologies in the process of organizing leisure activities in the conditions of recreation in summer camps.

We note that one of the effective forms of interactive learning is training. Its main feature is the feeling of new ideas on one's own experience, this is one of the conditions for the development of professional competence of future specialists. It should be noted that training in the form of training sessions is an unusual, unconventional form and a rather complex technological structure, the implementation of which by the teacher-trainer creates conditions for multilevel communication between all participants. One of the main requirements when using interactive methods - the coach's own participation in group interactive classes (Velichko, Karpievich, 2001:87).

This occurs under the condition of building an educational process based on learning by using specific experience developed by the American researcher D. Kolb (Thorn, Makkej, 2001:76). He considered the process of interaction in learning as a sequential change of four phases: 
- specific experience - it is assumed that the group leader creates conditions for the acquisition or updating of specific experience by participants on the basis of existing;

- reflective observation - conditions are created for the analysis of the acquired experience, discussion of the observations connected with its reception;

- abstract conceptualization - is the relationship of their own conclusions and inferences made in the previous stage, with scientific theories that are relevant to the main content of the curriculum. It is important that these theories complement or interpret in their own way the results obtained by the participants;

- active experimentation - is a test in practice of the formulated hypotheses, the use of previously obtained information.

In our work, we focused on training as an interactive form of learning, respectively, the specialist who conducted these classes was called a coach.

According to these ideas, the training process was implemented within the closely related components that formed the scheme of pedagogical interaction.

1. Purpose. The purpose of educational training was to raise awareness about the problem, change attitudes to the problem, the formation of positive motivation, creation and development of skills of adaptive behavior.

2. The content of the training was determined by the stated goal and target group.

3. Method. The method of training was understood as a method of teaching, i.e. a way of realization of the purpose of training limited by framework conditions, through interaction of subjects of educational activity.

4. Framework conditions. For an effective training process, organizational aspects were taken into account: the condition of the premises, selection of the necessary handouts, start and end times, training duration.

5. Participants. The target group to which the training was directed was determined. Just the target group influenced the goal and the content of the training process, according to which the training methods were selected.

6. Teacher-coach. Specialist, on the ability and qualification of which the success of the training process depended (Bachkov, 2000: 100).

In general, the structure of classes had three main elements: beginning, main part, final part.

The beginning of the training included the following components:

Introduction:

1. To define conditions of carrying out of training: it was necessary to define, to what problem study is devoted, what questions will be considered.

2. Determine the urgency of the problem: explain the reasons for this training, its advantages over others.

3. To interest participants. People are willing to learn when they are interested. It was necessary to demonstrate how interesting the training program was, how meaningful, useful and necessary was the information.

4. Present the program of training sessions: the concept of regulations, which clearly recorded the key points of training sessions (time and main elements).

5. Tell about yourself.

6. To acquaint participants of a training course. This procedure was performed using a variety of introduction techniques.

7. Create a favorable atmosphere. It was necessary to give the group the opportunity to discuss their anxieties, to determine their expectations, and thus to win their sympathy. 
8. Adopt the rules of work during training sessions. This part of the introduction was extremely important, as it was future-oriented and largely determined the effectiveness of the entire training process.

The main part was determined by the objectives and content of the training course. However, we note a few rules that were characteristic of the main part of the training.

1. Research of the subject. It was necessary to gather all the materials and information related to the topic of the training, it gave confidence to the trainer.

2. Distribution of the collected information on topics that the participants had to know.

3. Time distribution. An important component of the training course, because depending on the main tasks it was necessary to clearly define the time for coverage of problematic issues.

4. Organization of educational material.

The final part is an opportunity to:

1) give answers to questions that were insufficiently covered during the main part;

2) determine how effectively the group members have mastered the proposed material and provided information (theoretical material, practical skills);

3 ) determine whether the expectations of group members have been met;

4) to determine the prospects for the application of the acquired knowledge and skills in the real life of the participants.

The most popular methods used in the training sessions were: the case method (problem situations), brainstorming (brainstorming), discussion.

We will give an example of using the method of cases (problem situations) in practical classes on the subject "Methods of educational work in the camp". Students got acquainted with the strategy of behavior in conflict situations. The teacher announced the purpose of the lesson: to help make the conflict a positive rather than a negative experience in all cases where it is possible. Then he organized a group discussion on the following issues:

- Is it possible to manage without conflict in life?

- How often do we face conflicts?

-What is a conflict?

The next step was the simulated creation of a conflict situation.

Examples of conflict analysis.

- Conflict between the counselor and the child over the evaluation of his work. This may be a "violation of the rules of the game" (if the teacher is not really objective and has different requirements for different children). It can be a conflict of values (different ideas about the good and bad answer; what the child should know and how to respond). Finally, it can be a purely psychological, personal conflict.

- Conflict between teachers-organizers over the schedule. This can be a conflict of lack of resources: it is usually not possible to build a schedule to suit everyone.

- Conflict between the counselor and the child due to the fact that the child refuses to participate in the collective creative work. This is most likely a conflict of interest. The teacher is interested in the child performing well in the competition and showing good results of the counselor's work were noticed. The child does not want to spend time repeating and studying the "unnecessary" scenario of the educational event.

- The counselor was a little late, and the whole detachment left the holiday. This may be a conflict over the uncertainty of functions and responsibilities. (It is not written how many minutes the children have to wait for the counselor when he is late. The children have decided5 minutes, the counselor thinks more). 
- The child was reprimanded for making noise during the educational event. This is often a conflict of interest. The teacher is interested in the working environment, the child feels a natural need for activity.

In the practical classes, we discussed with the participants received information, asked questions in order to make students understand that finding those responsible for the conflict does not solve the problem, and this is not where we should focus our efforts:

- Is it always possible to determine in a conflict who is right and who is wrong?

- If we find the culprits, does that mean we have resolved the conflict?

- Does the party found guilty always agree with such a decision?

- What approach to conflict illustrates the desire to find the culprit? (Approach from the position of force, as usual, provides for some sanctions against the perpetrator).

- What is more important: to assess what has already happened, or to find a solution on how to proceed in the current situation in future?

- How can this conflict be resolved?

- How are such conflicts usually resolved?

As a result of the discussion, the definition of the conflict was formulated together with the participants.

Conflict is a clash of opposing, incompatible tendencies (needs, interests, values, attitudes, plans, etc.) in the mind of an individual, in interpersonal interactions and interpersonal relationships of individuals or groups of people.

Concluding that conflict is a normal and necessary part of our lives, the Teacher talked about the types of behavior in conflict, illustrating the basic strategies of behavior, using the classic conflict example "Distribution of orange". Then he talked about strategies for behavior in conflict.

Example "Distribution of orange" (Bachkov, 2000: 97).

Free orange catches the eye of two people at the same time, and each of them at the moment the orange would not interfere. What shall I do?

- An orange can be divided, right? This is a strategy of compromise.

- Each party can take possession of the fruit personally, using physical strength, social status, psychological influence, age or gender privileges.

- Orange can be disposed of as follows: throw it out the window, give to a third party, crush. This is a strategy of evasion: no object - no conflict.

The fruit may become the property of one of the parties of the conflict as a result of the selfless act of another. It is a strategy of concession - the abandonment of one's own goals for the sake of another person's goals.

Finally, the situation around the orange can be solved in this way.

Two happy citrus owners sit down at a round table to slowly discuss mutual expectations, fears and anxieties. During the conversation, it may turn out that one of them needs orange juice due to beriberi, and the other needs orange peel. The orange is festively cleaned, and the opponents leave completely satisfied. This option is called cooperation.

The practical lesson was about strategies for behavior in conflict.

Evasion is effective in situations where the partner has objectively greater power (authority) and uses it in a conflict of rank. When communicating with a complex, conflicted person, you should also use every opportunity to avoid conflict.

Flexibility is natural in situations where the problem is not as important to the person as to his opponent, or the relationship with him is an independent value: they are more important than achieving a goal. 
Counteraction is a strategy for serious circumstances and vital problems. It is usually effective in extreme situations.

Compromise, or "bargaining for mutual concessions" is effective in situations that require a quick result. "Division" of needs is necessary to maintain the relationship, especially in cases where it is really impossible to reconcile the interests of the parties.

Cooperation is not so much a strategy of behavior as a strategy of interaction. It is indispensable in close, long and valuable for both partners relationship, with equal status and psychological power. It allows partners to resolve the conflict without giving up their goals (Bachkov, 2000: 103).

The teacher offered to analyze the sources of conflicts:

- Lack of resources. Occurs when something is very small and not enough for everyone. ("We shared an orange. Many of us, and he - one ...")

- Differences in values. There are people with different beliefs, with different ideas about what is bad and what is good.

- Conflict of goals and interests. This occurs when actions aimed at achieving the goals of one person hinder the achievement of the goals of another or when the most convenient for one party behavior (state of affairs) is extremely inconvenient for the other party.

- Differences in tastes and preferences ("There is no friend to taste and color").

- Violation of the rules. Occurs when someone violates an agreement or mutual rules.

- Uncertainty of functions and responsibilities. This happens when the rules are simply not set and everyone understands them the way he wants, and then accuses the other that he understands them in his own way.

- Psychological needs. It is important for everyone to feel confident, needed, free, responsible. If the actions or presence of another interfere with the satisfaction of these needs, there is a personal (psychological) conflict (Velichko, Karpievich, 2001:99).

Participation of students in practical classes in interactive trainings provided an opportunity to carry out, meeting the needs of the individual, the following types of activities: communication with peers, organization of meaningful leisure, testing their own strength, finding their place in society.

The trainings helped to meet the basic needs of the individual in a variety of creative activities, recognition and respect from others, self-realization and self-affirmation, satisfaction and success, contributed to the development of social competence and responsibility.

Students' participation in interactive activities formed certain life skills necessary for personal development. These include in particular the following skills:

- effective communication (which were practiced at the formal (conducting classes) and informal (personal) levels);

- awareness of one's own individuality;

- understanding the individuality and uniqueness of other people;

- independent decision-making, self-control of their own behavior, self-esteem, self-awareness;

- leisure culture;

- ability to adapt to changes in the social environment.

In the course of interactive training activities, participants practiced the ability to carry out reflective and self-assessment activities, goal-setting, which was one of the components of the "self-concept" of the individual (Klarin, 1995: 78).

In the process of organizing interactive training work in practical classes on the subject "Methods of educational work in the camp" (for example, trainings "Strategies of behavior 
in conflict", "My approach to conflict"), we have consistently identified such stages (procedures) as:

- assessment of the need, resources and opportunities for the use of training;

- training of specialists (teachers-coaches) to organize and conduct work in children's health and recreation facilities;

- organizational and methodological support by teachers-specialists of classes by students-instructors during the "School of counselors";

- monitoring the activities of specialists and students-instructors in children's health and recreation facilities;

- correction of the activities of teachers-specialists and students-instructors in accordance with the results of monitoring (Pometun, Pirozhenko, 2002: 99).

When planning and organizing interactive training work, we defined the purpose, objectives, expected end result, sequence of procedures (stages), methods, tools and techniques of tasks performance, goal achievement, methods of evaluation and monitoring.

Interactive pedagogical technology as a set of successive actions aimed at achieving the result was based on the following principles: voluntariness, positivity, responsibility, partnership.

The principle of voluntariness provided for free choice by participants of their participation in leisure activities.

The principle of positivity provided that the "information link" in summer leisure activities to promote health should be based on the following conceptual provisions: health is the highest value, life can and should be satisfying, and the individual must make the most of opportunities to achieve well-being. in all spheres of life.

The principle of responsibility was based on the fact that the participation of students in leisure activities required them to take some responsibility for the end results, as well as willingness to be responsible for their own actions and deeds (in today's world the problem of responsibility is becoming increasingly important). It allowed to create conditions for participants not only to receive the necessary information, but also to have the opportunity to develop important life skills of effective communication, responsible decision-making, self-control of their own behavior, adaptation to changes in the social environment.

The principle of partnership was that the interests and feelings of all subjects were constantly taken into account in the educational process and interpersonal communication.

\section{Conclusions}

Interactive techniques (case method (problem situations), brainstorming, discussion) allowed to create conditions for participants not only to receive the necessary information, but also to be able to form important life skills of effective communication, responsible decision making, self-control of their own behavior, adaptation to changes in the social environment.

The principles of voluntariness, positivity, responsibility, partnership were formed, which meant that in the educational process and interpersonal communication the interests and feelings of all subjects were constantly taken into account.

We see prospects for further development in the study of the potential of interactivity in the context of creating guidelines for the implementation of training, innovative modeling in the training of future professionals during the organization of leisure activities in children's summer health and recreation camps. 


\section{References}

Bachkov I. V. (2000). Osnovy tekhnologii gruppovogo treninga [Fundamentals of group training technology]. Moscow: Psikhotekhniki. [in Russian].

Kej Torn, Dehvid Makkej. (2001). Trening - nastol'naya kniga trenera [Training - coach's handbook]. Sankt-Peterburg. [in Russian].

Klarin M. V. (1995). Innovatsii v mirovoj pedagogike: obuchenie na osnove issledovaniya, igry, diskussii (analiz zarubezhnogo opyta) [Innovations in world pedagogy: learning based on research, games, discussions (analysis of foreign experience)]. Riga. [in Russian].

Pometun O., Pyrozhenko L. (2002). Interaktyvni tekhnolohii navchannia: teoriia, praktyka, dosvid [Interactive learning technologies: theory, practice, experience]. Kyiv: A.P.N. [in Ukrainian].

Velichko V. V., Karpievich D. V. (2001). Innovatsionnye metody obucheniya v grazhdanskom obrazovanii [Innovative teaching methods in civic education]. Minsk. [in Russian].

Zaveryko N. V. (2004). Teoretychni zasady sotsialno-pedahohichnoi tekhnolohii roboty z pidlitkamy [Theoretical bases of social and pedagogical technology of work with teenagers]. Kiev: Naukovyi chasopys NPU imeni M. P. Drahomanova. [in Ukrainian].

Zymivets N. V. (2002). "Rivnyi-rivnomu” yak sotsialno-pedahohichna tekhnolohiia formuvannia zdorovoho sposobu zhyttia pidlitkiv ["Peer to peer" as a socio-pedagogical technology for the formation of a healthy lifestyle of adolescents]. Lutsk: Problemy pedahohichnykh tekhnolohii. Vyp. 2. [in Ukrainian]. 